\title{
PERILAKU SOSIAL ANAK PEKERJA BATU KALI DI KAMPUNG TAPAK LEBAR
}

\author{
Mansyur Romadon Putra \\ e-mail: mansyurromadonputra@rocketmail.com \\ STKIP-PGRI Lubuklinggau \\ JI. Mayor Toha Kota Lubuklinggau - Sumatera Selatan
}

\begin{abstract}
Abstrak: Penelitian ini bertujuan untuk mencermati perilaku sosial anak di kampung Tapak Lebar dengan situasi sosial yang primitif berada di pinggiran sungai. Subjek Penelitian anak usia 5-6 tahun yang berjumlah 3 orang anak. Adapun waktu penelitian dilakukan selama 8 bulan sejak Januari 2015 hingga Agustus 2015 Penelitian ini merupakan penelitian kualitatif dengan jenis penelitian studi etnografi. Analisis data yang digunakan yaitu model Spradley. Data penelitian ini diperoleh dari observasi, dokumentasi, dan pembuatan catatan lapangan. Hasil temuan penelitian ini menunjukkan bahwa : Perilaku sosial anak kampung Tapak Lebar dalam berinteraksi tidak mencerminkan etika dan kesopanan yang sesuai dengan budaya sopan santun. Dari hasil penelitian ini direkomendasikan agar diadakan sosialisasi oleh pemerintahan setempat terutama dalam mengantisipasi dan menanggulangi perilaku sosial anak pinggiran sungai dengan mendirikan lembaga pendidikan untuk anak-anak.
\end{abstract}

Kata-kata Kunci : anak , perilaku sosial, budaya.

\section{SOCIAL BEHAVIOUR OF THE CHILDREN OF RIVER STONE LABOUR IN TAPAK LEBAR VILLAGE}

\begin{abstract}
: the purpose of this study is to describe the social behavior of the children of river stone labour in Tapak Lebar village in a primitive social condition along the river bank. As the research subjects, the research involved three children of 5-6 years old. The research was conducted for 8 (eight) months starting from January through August 2015. The research belonged to qualitative research and was classified as an ethnography research. The data was collected by observation, document study, field notes to be analyzed employing Spradley model. The research findings indicate the social behavior of the children in Tapak Lebar village in interacting each other do not reflect etiquette and politeness suitable to polite culture. It is recommended that the local government implement socialization program to anticipate and to prevent the social behavior of the river bank children by establishing educational institutions for them.
\end{abstract}

Keywords: child, social behavior, culture.

\section{PENDAHULUAN}

Usia dini merupakan masa keemasan bagi setiap individu, masa ini sangat penting karena merupakan masa yang menentukan perkembangan selanjutnya. Usia dini merupakan waktu dimana bermuaranya semua aspek perkembangan, setiap individu berawal dari kelahiran kemudian tumbuh dan berkembang menjadi individu dewasa, pertumbuhan dan perkembangan tersebut dimulai dari awal kehidupan.

Menurut Frobel "anak usia dini diibaratkan seperti tunas tumbuh-tumbuhan, masih memerlukan pemeliharaan dan perhatian sepenuhnya dari si juru tanam" (Direktorat PAUD 2013). Dalam arti bahwa anak diusianya yang dini merupakan masa fundamental yang masih perlu diarahkan.
John Locke menyatakan bahwa anakanak diibaratkannya seperti "papan kosong" ia menyatakan bahwa pengalaman masa kanak-kanak sangat menentukan karakteristik seseorang ketika dewasa (Suntrock, 2007). Hal ini sejalan dengan pendapat Frobel tentang anak usia dini merupakan individu dimana peletakan pondasi awal yang menentukan perkembangan selanjutnya.

Anak usia dini menurut NationalAssociation for The Education of Young Children adalah individu dengan rantang usia antara 0 sampai 8 tahun. Pada tahap ini perkembangan anak sangat maksimal, di usia keemasannya otak anak berkembang $80 \%$, masa usia dini sangat menentukan perkembangan kedepan, perkembangan anak tersebut dipengaruhi 
oleh beberapa faktor, baik faktor genetis, maupun faktor lingkungan. Usia lahir sampai 8 tahun mengalami masa perkembangan dan pertumbuhan yang sangat pesat, pada masa keemasan ini merupakan masa kritis dalam tahapan kehidupan manusia, yang akan menentukan perkembangan anak selanjutnya.

Setiap anak atau individu memiliki kebutuhan yang harus dipenuhi terutama bagi anak usia dini agar perkembangannya baik maka kebutuhannya harus diperhatikan selain kebutuhan makan dan minum yang sehat dan bergizi anak juga membutuhkan kebutuhan lain seperti kebutuhan akan cinta kasih, kebutuhan bereksplorasi, dan kebutuhan akan waktu bermain untuk mengaktualisasikan dirinya. Kebutuhan dasar manusia merupakan unsur-unsur yang dibutuhkan oleh manusia dalam mempertahankan keseimbangan fisiologis maupun psikologis, yang tentunya bertujuan untuk mempertahankan kehidupan dan kesehatan.

Maslow mengemukakan tentang hierarki kebutuhan manusia bahwa setiap manusia memiliki lima kebutuhan dasar yaitu kebutuhan fisiologis, keamanan, cinta, harga diri, dan aktualisasi diri (Dodge, 1992) Kebutuhan tersebut tersusun pertahap membentuk hierarki, kebutuhan terakhir aktualisasi diri akan terpenuhi apabila kebutuhankebutuhan sebelumnya telah terpenuhi.

Hierarki kebutuhan manusia mengatur kebutuhan dasar dalam lima tingkatan prioritas. Tingkatan yang paling dasar, atau yang pertama meliputi kebutuhan fisiologis seperti: udara, air dan makanan. Tingkatan yang kedua meliputi kebutuhan keselamatan dan keamanan, yang melibatkan keamanan fisik dan psikologis. Tingkatan yang ketiga mencakup kebutuhan cinta dan rasa memiliki, termasuk persahabatan, hubungan sosial dan cinta seksual. Tingkatan yang keempat meliputi kebutuhan rasa berharga dan harga diri, yang melibatkan percaya diri, merasa berguna, penerimaan dan kepuasan diri. Tingkatan yang terakhir adalah kebutuhan aktualisasi diri (Papalia, 1991)

Dengan mengetahui konsep kebutuhan menurut Maslow, kita perlu memahami bahwa manusia senantiasa berkembang, sehingga dapat mencapai potensi diri yang maksimal. Kebutuhan pada tingkat yang lebih tinggi tidak akan terpenuhi dengan baik sampai kebutuhan dibawahnya terpenuhi. Jika kebutuhan dasar pada tiap tingkatan tidak terpenuhi, pada akhirnya akan muncul sesuatu kondisi patologis. Setiap orang mempunyai kebutuhan dasar yang sama dan setiap kebutuhan tersebut dimodifikasi sesuai dengan budaya masing-masing. Setiap orang memenuhi kebutuhan dasarnya menurut prioritas. Dalam hal ini individu memenuhi kebutuhannya berdasarkan tingkatan kebutuhan yang diperlukan.

Menurut Marrison teori anak adalah pernyataan prinsip dan gagasan yang mencoba menjelaskan kejadian dan bagaimana hal-hal terjadi yaitu mempelajari pendidikan anak usia dini (Morisson, 2012). Masa usia dini (golden Age) hanya akan datang sekali yakni pada rentang usia 0-8 dan tidak dapat diulangi, masa ini juga sangat menentukan pengembangan kualitas manusia.

Benyamin S. Bloom, Keith Osborn, dan Burton L, White, mengemukakan bahwa sekitar $50 \%$ kapasitas kecerdasan seseorang telah selesai terbentuk saat anak berusia 4 tahun. Peningkatan $30 \%$ berikutnya terjadi pada rentang usia 4 hingga 8 tahun, dan $20 \%$ sisanya pada rentang usia 8 hingga 18 tahun. Ini artinya, kecerdasan yang terbentuk pada rentang 4 tahun pertama sama besarnya dengan peningkatan kecerdasan pada rentang usia 14 tahun hingga berikutnya. Pada usia 6 tahun perkembangan kecerdasan anak telah mencapai 70\% (Kerangka Besar Pembangunan PAUD, 2011)

Huttenlocher menekankan pentingya masa usia dini dalam mengoptimalkan perkembangan otak anak (Kerangka Besar Pembangunan PAUD Indonesia 2011). Oleh sebab itu, masa usia dini adalah saat yang paling penting dimana perkembangan anak akan menentukan perkembangan dimasa mendatang.

Dari beberapa pendapat di atas dapat disimpulkan bahwa anak usia dini adalah individu yang berada pada rentang usia 0-8 tahun dimana bermuaranya seluruh aspek perkembangan kognitif, fisik, dan sosial emosional yang berpengaruh terhadap perkembangannya ke depan.

Pentingnya masa usia dini sebagai pondasi awal yang menentukan perkembangan berikutnya merupakan hal yang penting untuk pertumbuhan dan perkembangan individu yang baik, baik secara fisik maupun psikis. Agar pertumbuhan individu berkembang optimal maka perlu diberikan stimulasi.

Syarief berpendapat bahwa pertumbuhan dan perkembangan anak saat dini bahkan sejak dalam rahim hingga usia 6 tahun sangat menentukan 
derajat kesehatan, intelegensi, kematangan emosional, dan produktivitas manusia pada tahap berikutnya.

Perkembangan anak usia dini tentunya dipengaruhi oleh berbagai faktor, diantaranya dipengaruhi oleh genetik dan faktor lingkungan, pengaruh genetik didukung oleh situasi budaya di mana individu tinggal menentukan pola perkembangan dari setiap individu.

Pada penelitian ini budaya yang sangat kental serta genetik yang secara turun-temurun menjadi faktor yang paling dominan, terutama dalam perilaku sosial anak. Dalam aktivitas keseharian anak indikasi-indikasi perilaku dalam kehidupan sosial tercermin dari etika budaya ketika berinteraksi, situasi sosial memberi pengaruh besar terhadap perkembangan perilaku sosial anak.

Perilaku sosial merupakan aktivitas yang berhubungan dengan orang lain, baik dengan teman sebaya, guru, orang tua maupun saudara, ketika anak berhubungan dengan orang lain, terjadi peristiwa-peristiwa yang sangat bermakna dalam kehidupannya yang dapat membantu pembentukan kepribadiannya. Sejak kecil anak telah belajar berperilaku sesuai dengan harapan orang-orang disekitarnya, yaitu dengan ibu, ayah, dan saudaranya. Kehidupan sosial tidak dapat dipisahkan dari interaksi antarindividu, interaksi yang terjalin merupakan tindakan berupa perilaku. Perilaku yang terjadi biasanya merupakan tindakan sehari-hari di kehidupan anak. Apa yang dipelajari anak dari lingkungan keluarganya turut mempengaruhi pembentukan perilaku sosialnya

Perkembangan sosial berhubungan dengan perilaku anak dalam menyesuaikan diri dengan aturan-aturan masyarakat dan lingkungannya. Perkembangan sosial diperoleh anak melalui kematangan dan kesempatan belajar dari berbagai stimulus dari lingkungannya, perkembangan sosial mengikuti pola tertentu, yang sama pada semua anak dari kelompok budaya tertentu.

Menurut Hurlock pada usia 5-6 merupakan usia berkelompok, anak tidak lagi puas bermain sendiri di rumah atau dengan saudara-saudara kandung atau melakukan aktivitas dengan anggota keluarga. Anak ingin bersama teman-temannya dan akan merasakan kesepian serta tidak puas bila tidak bersama teman-temannya (Hurlock, 1992). Hal ini menandakan bahwa sosial anak sudah mulai meluas dan berkembang dari usia sebelumnya, apabila pada usia sebelumnnya anak hanya berinteraksi dengan orang tua dan anggota keluarga, di usia 5-6 tahun anak sudah memiliki teman sebaya.

Menurut Suntrock proses sosial emosi melibatkan perubahan dalam hubungan seseorang dengan orang lain, perubahan emosi, dan perubahan dalam kepribadian. Yakni perilaku sosial emosi dipengaruhi oleh stimulus seperti senyuman seorang bayi karena sentuhan ibunya, serangan seorang anak laki-laki pada teman bermainnya.

Menurut Mulyasa, Perilaku sosial atau non sosial yang dibina pada awal masa kanak-kanak akan sangat menentukan kepribadiannya, baik melalui pengalaman yang menyenangkan maupun tidak menyenangkan, berupa hubungan dengan anggota keluarga atau dengan orang-orang diluar keluargaa (Santrock, 2007). Hal ini menyatakan bahwa pengalaman memeiliki peranan penting dan memiliki pengaruh terhadan perilaku sosial seseorang.

Hubungan antar individu menjadi dasar pengertian sosial. Menurut Drisscol and Nagel, sosial context is as a member of a group (Santrock, 2007) Hal ini berarti bahwa secara kontekstual pengertian sosial adalah anggota yang berhubungan dalam sebuah kelompok. Selain itu hubungan tersebut menimbulkan kencenderungan kecenderungan dan impuls yang berhubungan dengan kelompok yang terorganisir lainnya. Jadi, pengertian sosial berkaitan dengan hubungan yang saling berkaitan antarindividu dan membentuk jalinan kuat dalam sebuah kelompok.

Secara mendalam, hubungan antarindividu yang saling berkaitan satu sama lain membutuhkan sebuah keahlian. Schickedanz menjelaskan social development is the child ability to think about a situation from another pearson's point of view understand what causes that person to behave in acertain way and how children actually behave toward another and toward adults in their lives (Santrock, 2007). Menurut pendapat tersebut dapat diartikan bahwa perkembangan sosial adalah kemampuan seorang anak untuk berpikir tentang sebuah situasi dalam memahami sudut pandang orang lain, hal apa saja yang dilakukan oleh seseorang pada beberapa cara tertentu dan bagaimana anak seharusnya bertindak dengan beberapa orang dan dengan orang dewasa di kehidupan mereka. Hal ini menunjukkan bahwa perkembangan sosial pada anak muncul ketika 
anak sudah mulai merasakan keberadaan orang sekitar di dalam kehidupannya. Dengan begitu anak tidak sekedar memandang dari sudut pandang diri sendiri, namun memiliki kepedulian kepada orang disekitarnya.

Perkembangan sosial anak ditandai dimana anak mulai memahami keberadaan orang sekitar. Pendapat tersebut diperkuat oleh pernyataan Brooker and Broadbent bahwa perkembangan sosial merupakan learning through the child's own exploration of the environment, learning through interaction with peers and siblings dan learning with adult support and guidance (Santrock, 2007). Pernyataan ini menunjukkan bahwa perkembangan sosial meliputi tiga kemampuan dasar untuk belajar berekplorasi dari lingkungannya, belajar berinteraksi dengan teman sebaya dan belajar sesuai dengan tuntutan sosial yang ada dari orang dewasa.

Kemampuan berperilaku sosial pada perkembangan sosial anak melalui serangkaian proses secara sadar yang dialami setiap anak. Hal serupa diungkapkan oleh Gordon dan Browne menyatakan bahwa social development of a child reflects the standards and values of her family and of her society, where the cild begins to learnacceptable or appropriate behaviors at birth and continues to learn behavior patterns through her relationships with other, adapting these behaviors to her unique personality (Driscoll, 2005)

Hal tersebut menerangkan bahwa perkembangan sosial merupakan kesadaran seorang anak untuk memahami nilai-nilai yang berada dalam keluarga dan masyarakat. Anak mulai mempelajari atau menyesuaikan sikap pada saat awal kehidupan dan berlanjut untuk mempelajari pola perilaku dalam berhubungan dengan orang lain. Interaksi tersebut melalui sebuah proses adaptasi dengan perilaku-perilaku unik. Pernyataan tersebut menandakan bahwa perkembangan sosial adalah usaha sadar yang dilakukan dalam memahami nilainilai yang ada melalui serangkaian proses. Proses ini menitikberatkan pada adaptasi seseorang dalam memahami perilaku-perilaku unik akan menciptakan sebuah hubungan antarindividu.

Bandura menyatakan bahwa "Behavior can influence person/ cognitive factors and vice versa. The person's cognitive activities can influence the environment, the environment can change the person's cognition, and so on" (Santrock, 2007) Hal ini menyatakan bahwa perilaku dapat mempengaruhi seseorang, ada korelasi antara perilaku seseorang dengan lingkungan, baik kognitif terhadap lingkungan, maupun sebaliknya hingga seterusnya. Dalam hal ini lingkungan yang dimaksud adalah tempat dimana anak berada, oleh karena itu perolehan kemampuan berprilaku sosial tersebut melibatkan komponen keluarga, sekolah dan masyarakat.

Erickson menyatakan dalam teori psikososialnya bahwa motivasi utama manusia bersifat sosial dan mencerminkan suatu keinginan untuk berhubungan dengan orang lain (Santrock, 2007). Teori ini menjelaskan bahwa hakikatnya individu memiliki sifat interaksi yang merupakan kebutuhan dari setiap individu. Karena pada dasarnya tanpa berinteraksi individu tidak dapat memenuhi kebutuhannya sehingga tidak dapat mempertahankan kehidupannya tanpa bersosialisasi, karena kebutuhan dapat terpenuhi adanya interaksi yang terjadi.

Pavlov menyatakan bahwa perilaku didasari dari pola kebiasaan, hal ini ia buktikan dari risetnya di awal tahun 1900an, dari hasil riset tersebut membuktikan bahwa pola kebiasaan memberi pengaruh besar terhadap perilaku. Kebiasaankebiasaan dalam kehidupan sehari-hari yang berupa tindakan merupakan bentuk dari perilaku.

Adapun pola perilaku sosial anak usia 5-6 tahun yaitu Kerja sama, persaingan, kemurahan hati, hasrat akan penerimaan sosial, simpati, empati, ketergantungan, sikap ramah, sikap tidak mementingkan diri sendiri, meniru, perilaku kelekatan (attachment behavior), dan berkelompok (Hurlock, 2007) Perilaku-perilaku yang demikian biasanya muncul sejak individu berada diusia kanak-kanak.

Dari beberapa pendapat teori di atas dapat ditarik kesimpulan bahwa perilaku sosial adalah tindakan interaksi antarindividu dalam membangun hubungan yang saling berkaitan, dan perilaku sosial individu dipengaruhi oleh berbagai faktor, yang paling dominan adalah faktor lingkungan atau budaya di mana individu itu berada, berdampak pada pola kebiasaan yang lama-lama menjadi ciri khas suatu perilaku dari individu tersebut.

Masa usia dini merupakan tahapan awal dimana bermuaranya semua perkembangan, tidak hanya kemampuan intelektual yang dikembangkan tetapi perilaku juga tidak kalah pentingnya untuk mengimbangi perkembangan individu sebagai bekal 
di masa mendatang, atas dasar pertimbangan hal tersebut dan berdasarkan kenyataan di lapangan daerah penelitian bahwa banyak sekali anakanak yang berperilaku anarkis dalam berinteraksi, berdasarkan survey pra-observasi awal ditemui aktivitas kekerasan yang dilakukan anak, selain itu berdasarkan data dari kelurahan setempat bahwa angka anak yang tidak bersekolah lumayan banyak, hal ini membuat peneliti ingin mencermati bagaimana perekembangan perilaku sosial anak di daerah tersebut serta hal lain yang berkaitan dengan perilaku anak yang ditemukan dilapangan.

Adapaun rumusan masalah dari penelitian ini adalah bagaimana perilaku sosial anak pekerja batu kali usia 5-6 tahun di kampung Tapak Lebar. Manfaat penelitian ini secara teoretis dapat menambah pengetahuan, wawasan, dan jumlah referensi ilmiah berkaitan dengan anak usia dini yang tinggal di daerah perkampungan dengan ciri keunikan pada komunitas tertentu sedangkan secara praktis bagi pengambil kebijakan hasil penelitian ini diharapkan dapat memberikan gambaran kepada lembaga setempat terutama pemerintah untuk lebih memperhatikan kehidupan anak usia dini yang tinggal di perkampungan Tapak Lebar, bagi masyarakat Kampung Tapak Lebar hasil penelitian ini diharapkan mampu dijadikan refleksi dan dapat memberikan gambaran secara kognitif kepada masyarakat yang tinggal di sekitar sungai kelingi tentang pentingnya masa anak usia dini, bagi Peneliti hasil penelitian ini diharapkan dapat memberikan informasi dan menambah pengetahuan mengenai Anak Usia Dini yang tinggal di pinggir sungai Kelingi kampung Tapak Lebar.

\section{METODE PENELITIAN}

Metode yang digunakan dalam penelitian ini adalah penelitian kualitatif dengan pendekatan etnografi. Tempat penelitian yaitu di wilayah kelurahan Tapak Lebar, tepatnya di pinggiran sungai kelingi, kecamatan Lubuklinggau Barat II, Sumatera selatan. Waktu penelitian dilakuan sejak awal januari 2015 hingga Agustus 2015 (8 bulan)

Untuk mencermati perilaku sosial tersebut dipilih anak sebagai sumber data atas dasar pertimbangan tertentu, yaitu dengan pertimbangan sumber penelitian mampu menjawab hal-hal yang akan peneliti amati, selain itu didukung oleh informasi yang didapat dari informan, adapun subjek penelitiannya adalah anak dalam rentang usia 5-6 tahun sebanyak 3 orang.

Teknik pengumpulan data dilakukan dengan cara pengamatan langsung observasi berperan serta, wawancara mendalam, dan mengumpulkan berbagai dokumen terkait dengan pengasuhan, wawancara dilakukan dengan informan dan subjek penelitian dengan pendekatan wawancara tidak terstruktur dan pendekatan informal, analisis data bersifat induktif, dan hasil penelitian kualitatif lebih menekankan makna daripada generalisasi. Sumber-sumber data dari penelitian ini antara lain:
Masyarakat budaya, seperti tokoh masyarakat, tokoh adat, masyarakat setempat dan budaya masyarakat kampung Tapak Lebar. Subjek penelitiannya adalah anak usia 5-6 tahun.

Prosedur penelitian ini secara garis besar dilakukan melalui empat tahapan kegiatan, yaitu (1) tahap pra-lapangan, (2) pelaksanaan, (3) analisis data, dan (4) diakhiri dengan penulisan laporan. Analisis data yang digunakan adalah analisis data model Spradley, analisis data dilakukan sejak sebelum memasuki lapangan (studi pendahuluan) ketika di lapangan dan ketika selesai di lapangan, untuk keakuratan data juga divalidasi dengan triangulasi dari berbagai sumber data. Adapun tahapan yang dilakukan pada saat analisis mengacu pada model Spradley yang terdiri dari dua belas tahap, yaitu: (1) memilih situasi sosial, (2) melaksanakan observasi partisipan, (3) mencatata hasil observasi dan wawancara, (4) melakukan observasi deskriptif, (5) melakukan analisis domain, (6) melakukan observasi terfokus, (7) melaksanakan analisis taksonomi, (8) melakukan observasi terseleksi, (9) melakukan analsis, (10) melakukan analisis tema, (11) temuan budaya, dan (12) menuliskan laporan kualitatif (Sugiono, 2007).

\section{HASIL DAN PEMBAHASAN}

Hasil pengamatan yang telah dilakukan peneliti melalui analisis data dan triangulasi bahwa perilaku sosial anak dalam interaksi sehari-hari menunjukan indikasi-indikasi perilaku yang cenderung "aktif" yaitu ditunjukan dari pola komunikasi dan tindakan yang di lakukan anak dalam kehidupan sehari-hari, beberapa faktor penyebab yaitu budaya setempat dan kurangnya 
pendidikan yang diterima oleh masyarakat setempat terutama bagi anak-anak, sehingga dapat ditarik kesimpulan bahwa mayoritas anak usia dini terutama dalam rentang usia 5-6 tahun tidak bersekolah yang berdampak pada perilaku yang cenderung kurang sopan ketika berperilaku dalam berinteraksi sosial dikehidupan sehari-hari. Akibatnya perilaku yang cenderung kasar sudah menjadi kebiasaan bagi anak-anak setempat.

Perilaku yang terbentuk pada anak usia dini di kampung Tapak Lebar selain dipengaruhi lingkungan tempat domisili atau budaya setempat yang mayoritas penduduknya tidak mengenyam pendidikan sejalan dengan teori yang dikemukakan oleh Bandura (Suntrock, 2007:50) bahwa "Behavior can influence person/ cognitive factors and vice versa. The person's cognitive activities can influence the environment, the environment can change the person's cognition, and so on". Hal ini menyatakan bahwa perilaku dapat mempengaruhi seseorang, ada korelasi antara perilaku seseorang dengan lingkungan, baik kognitif terhadap lingkungan, maupun sebaliknya hingga seterusnya.

Dalam segala rutinitas tentunya tidak lepas dari interaksi, interaksi yang terjadi merupakan aplikasi dari perilaku sosial. Dalam hal sosial masyarakat kampung tapak lebar merupakan masyarakat yang memiliki solidaritas kemasyarakatan yang sama seperti masyarakat pada umumnya, hanya saja perilaku sosial anak-anaknya tidak mencerminkan budaya saling bantu, terutama dalam hal pekerjaan. Namun hal ini sangat beralasan karena anak tersebut berlomba-lomba untuk mengumpulkan batu.

Beberapa hasil penelitian yang relevan dengan penelitian ini,mengenai pengasuhan dan kehidupan anak usia dini pada suatu masyarakat tertentu. Masayo Uji, Ayuko Sakamoto, Keichiro Adachi, Toshinori Kitamura pada penelitiannya The Impact Of Authoritative, authotarian, and permisive parenting Styles on Children's later mental Helth in Japan: Focusing on parent and child gender. Pada penelitian ini melihat efek dari gaya pola pengasuhan otoriter, otoritarian, dan permisif terhadap kesehatan mental anak, perbedaan dengan penelitian yang dilakukan yaitu penelitian di kampung tapak lebar melihat pola pengasuhan, perilaku sosial dan motorik anak.

Betty Rintoul, Judy Thorne, Ina Wallace, Margaret Mobley, Jennife Goldman Fraser,
Heather Luckey dalam penelitiannya Personal Characteristics and parentel behavior (Ebsco, 2012). Kesamaan dengan penelitian yang dilakukan adalah sama-sama mengkaji tentang perilaku anak, sementara perbedaannya, yaitu untuk meilhat karakter kepribadaian dan perilaku pengasuhannya, sementara peneiltian yang dilakukan melihat perilaku sosial pengasuhan yang diterapakan.

Ozcan Dagdemir dan Hakan Acaroglu, pada penelitiannya yang berjudul The Effects of Globalization on Child Labor in Developing Countries. Keterkaitan penelitian tersebut dengan penelitian ini adalah sama-sama tentang pekerja anak, perbedaannya adalah penelitian tersebut merupakan pekerja anak berdasarkan efek dari globalisasi sementara penelitian dilakukan adalah anak yang diperjakan berdasarkan latar belakang situasi peradaban setempat.

Tayyaba Zarif, Aiz-un-Nisa, Aijaz Ahmed, Mubashir Mirza dalam peneltiannya Understanding Reasons Of Child Labour In A Developing Economy: A Qualitative Study Of Karachi, Pakistan. Adapun keterkaitan dengan penelitian ini yaitu sama-sama tentang anak yang dipekerjakan perbedaanya adalah penelitian tersebut berorientasi pada alasan anak dipekerjakan dan perekonomian sedangkan penelitian ini pada kehidupan anak yang dipekerjakan dan perilaku sosialnya.

Kartika Rinakit Adhe, pada penelitiannya di desa Bojonegoro meneliti mengenai budaya kehidupan masyarakat samin dalam menanamkan karakter kejujuran kepada Anak Usia Dini, membahas tentang bagaimana penanaman dan pembiasaan karakter yang diterapkan oleh masyarakat tersebut, adapun judul tesisnya adalah "Ajaran Masyarakat Samin Pada Penanaman dan Pembiasaan Karakter" (Adhe, 2014) Keterkaitan antara penelitian tersebut dengan penelitian ini adalah sama-sama meneliti tentang kehidupan pada sekelompok masyarakat tertentu dengan keunikan-keunikan tersendiri yang menjadi ciri khas populasi penduduk yang menjadi subjek penelitian, selain itu menggunakan jenis penelitian yang sama. Bedanya penelitian tersebut lebih mengarah pada karakter sementara penelitian ini mengarah pada perilaku sosial, dan keterampilan motorik.

Dalam penelitian lainnya, Amanah Rahma Ningtias juga melakukan jenis penelitian yang sama dan mengkaji tentang karakter anak usia dini yang tinggal di daerah pesisir pantai. Penelitiannya 
berjudul "Karakter anak usia dini yang tinggal di daerah pesisir pantai". Kesamaan dengan penelitian ini adalah sama-sama membahas tentang pola kehidupan anak usia dini pada suatu komunitas daerah tertentu, dengan pola perilaku tertentu yang menciri khaskan keunikan.

\section{PENUTUP}

\section{Kesimpulan}

Berdasarkan hasil pembahasan yang telah dilakukan dan dikaitkan dengan teori yang sudah ada, maka ditarik kesimpulan bahwa perilaku sosial anak di kampung Tapak Lebar dipengaruhi oleh kebiasaan dan budaya daerah setempat. Pola kebiasaan perilaku hidup keras yang tercermin dari interaksi masyarakat terutama bagi anak-anak. Secara garis besar bahwa lingkungan sekitar memiliki peran penting dalam mempengaruhi perilaku sosial anak dalam berinteraksi di kehidupan sehari-hari.

\section{Saran}

Dari temuan dan informasi hasil penelitian, maka peneliti mengajukan beberapa rekomendasi kepada berbagai pihak. Bagi orang tua, membudayakan perilaku yang baik dengan bertuturkata yang bagus serta menjadi contoh yang pantas ditiru oleh anak-anak, bagi penentu kebijakan diharapakan mengadakan sosialisasi pada masyarakat tentang pentingnya masa usia dini sebagai pondasi awal dalam mengarahkan anak pada perilaku sosial yang baik dan bagi masyarakat meningkatkan kesadaran tentang pentingya masa usia dini sebagai pondasi perkembangan anak di usia selanjutnya.

\section{DAFTAR PUSTAKA}

Adhe, K. (2015). Ajaran masyarakat Samin pada penanaman dan pembiasaan karakter. Tesis tidak di terbitkan. Jakarta: PPs UNJ.

Depdikbud. (2011). Kerangka Besar Pembangunan PAUD Indonesia. Jakarta: Depdikbud

Driscoll, A., et, al. (2005). Early childhood education birth- 8. United States of America : Pearson Education.

Direktorat Pembinaan PAUD. (2013). Kerangka besar pembangunan PAUD Indonesia periode 2011-2025. Jakarta: Kemendikbud

Dodge, D.T.,\& Colker, L. J. (1992). The creative curriculum for early childhood. Washington DC: Teaching Strategies Inc.

Hurlock. (2007). Perkembangan anak jilid 1 (penerjemah: Meitasari Tjandrasa). Jakarta: Erlangga

Hurlock. (1992). Psikologi perkembangan suatu pendekatan sepanjang rentang kehidupan (penerjemah: Istiwidiyanti \& Soedjarwo).
Jakarta: Erlangga.

Morrison. (2012). Dasar-dasar pendidikan anak usia dini edisi ke lima (penerjemah: Suci Romadhon). Jakarta:Indeks.

Mulyasa. (2012). Manajemen PAUD. Bandung: PT. Remaja Rosdakarya

Ningtias, A. (2015). Karakter anak usia dini yang tinggal di daerah pesisir pantai. Tesis tidak diterbitkan Jakarta: PPs UNJ

Papalia. (1990). A child's world infancy through adolescenc. New York: McGRAW-HILL

Santrock (2007). Children ninth edition. New York: McGraw Hill

Santrock. (2007). Perkembangan anak. Alih bahasa Mila Rachmawati dan Anna Kuswanti Jakarta. Erlangga.

Shickedanz, et.al. (2001). Understanding children and adoelescents. Boston: A Pearson Education Company. 